\title{
PERLINDUNGAN KONSUMEN TERHADAP HAK KONSUMEN ATAS \\ KEAMANAN DALAM MENGKONSUMSI BARANG DARI TINDAKAN \\ PENGOPLOSAN BERAS
}

\section{Inne Christina}

(Mahasiswa Program S1 Fakultas Hukum Universitas Tarumanagara)

(E-mail: inne.christina.ic@gmail.com)

\section{Ermanto Fahamsyah \\ (Corresponding Authors)}

(Dosen Hukum Perlindungan Konsumen Fakultas Hukum Universitas Tarumanagara, Meraih Sarjana Hukum (S.H.) dari Fakultas Hukum Universitas Jember (2002), Magister Hukum (M.H.) dari Universitas Indonesia (2008), dan Doktor Ilmu Hukum (Dr.) dari Universitas Indonesia

(E-mail: ermanto_fahmsyah@yahoo.co.id, ermantofahamsyah@gmail.com)

\begin{abstract}
The proceedings of low-quality mixing of rice poses a threat to consumers. Article 4 UUPK states the consumer rights of safety and protection in consuming a product, receiving correct information, honest and true, and enables compensation of the item received is incorrect. Article 7 states the obligation of the company to show good faith in carrying out their responsibility and guarantee the quality of their product, ensuring they meet the standards accordingly. Violations also happen according to Food Regulation. In order to avoid futher violations, the government should supervise the operations of the market trade. Additionally, what kind of legal protection towards the consumers rights regarding the safety of consuming products from the low-quality mixing of rice and what is the role of the government in supervising such kind of distribution? This research will list out the problems addressed by using normative methods. Research data will observe the existing legal prodictions of UUPK and Food Regulation by suggesting sanctions to companies that violate the policies of UUPK and Food Regulation, as well as the supervision of the government as stated in PERMENDAG No. 20 Tahun 2009.
\end{abstract}

Keywords: Consumers Protecion, Consumers Rights, Safety, Low-quality Mixing of rice. 


\section{PENDAHULUAN}

\section{A. Latar Belakang}

Kegiatan perekonomian di era globalisasi pada sekarang ini berkembang semakin pesat. Kegiatan perekonomian berkembang seiring dengan dengan populasi masyarakat yang semakin meningkat. Salah satu kegiatan perekonomian yang berkembang seiring dengan perkembangan populasi masyarakat di Indonesia dan menjadi salah satu kebutuhan yang sangat pokok yaitu mengenai pangan. Pangan adalah segala sesuatu yang berasal dari sumber hayati produk pertanian, perkebunan, kehutanan, perikanan, peternakan, perairan, dan air, baik yang diolah maupun tidak diolah yang diperuntukkan sebagai makanan atau minuman bagi konsumsi manusia, termasuk bahan tambahan. ${ }^{1)}$

Masyarakat Indonesia pada hakekatnya memiliki kebutuhan khususnya makanan pokok yang berbeda dengan masyarakat di negara lain. Masyarakat Indonesia memiliki makanan pokok yaitu nasi. Nasi merupakan makanan pokok masyarakat Indonesia yang terbuat dari beras dengan bahan dasar yang bermula dari padi.

Masyarakat masa kini memiliki daya beli yang konsumtif dalam melakukan kegiatan transaksi dalam mengimbangi kebutuhan masyarakat yang terus meningkat. Hal ini menyebabkan beras menjadi suatu kebutuhan pangan yang sangat mendasar atau pokok bagi keberlangsungan hidup masyarakat Indonesia. karena dianggap sebagai suatu kebutuhan yang penting bagi masyarakat Indonesia, pemerintah kemudian didorong untuk melakukan tindakan pengawasan dan pengaturan perihal penyediaan beras, pemasaran beras serta kualitas dari beras yang diperjual-belikan di dalam masyarakat di seluruh Indonesia. Untuk itu, Pemerintah kemudian membuat suatu peraturan dalam bentuk undang-undang yang mengatur tentang Pangan, yaitu Undang-Undang Nomor 18 Tahun 2012 tentang Pangan (UU Pangan).

\footnotetext{
1) Indonesia, Undang-Undang Nomor 18 Tahun 2012 tentang Pangan (Lembaran Negara Republik Indonesia Tahun 2012 Nomor 227, Tambahan Lembaran Negara Republik Indonesia Nomor 5360), Pasal 1 ayat (1).
} 
Pemerintah dalam hal pengadaan beras ini bersama-sama dengan masyarakat melakukan kegiatan jual-beli beras guna merealisasikan kegiatan pengadaan beras untuk masyarakat di seluruh Indonesia. Kegiatan ini secara tidak langsung menimbulkan kegiatan usaha yang kemudian diatur perlindungannya bagi para pembeli atau konsumen dalam Undang-Undang Nomor 8 Tahun 1999 tentang Perlindungan Konsumen (UUPK). Perlindungan konsumen adalah segala upaya yang menjamin adanya kepastian hukum untuk memberi perlindungan kepada konsumen $^{.2)}$ UUPK mengatur hak konsumen ${ }^{3)}$, kewajiban konsumen ${ }^{4)}$, hak pelaku usaha ${ }^{5)}$, kewajiban pelaku usaha6), perbuatan pelaku usaha apa saja yang dilarang ${ }^{7)}$ sampai dengan penyelesaian apabila terjadi sengketa antara keduanya.

Permasalahan antara pelaku usaha dengan konsumen sering kali tibul walaupun sudah diatur sedemikian rupa oleh undang-undang. Permasalahan yang timbul ini sering kali disebabkan oleh tindakan pelaku usaha yang tidak beritikad baik dan menyebabkan kerugian sehingga hak-hak konsumen yang seharusnya dapat diterima oleh konsumen menjadi dilanggar oleh pelaku usaha tersebut. Hal ini dapat kita lihat dalam tindakan pengoplosan beras yang dilakukan oleh beberapa pelaku usaha di Indonesia, seperti tindakan pengoplosan yang dilakukan oleh pemilik Toko Beras Jaya Abadi di Pangkalpinang, Bangka Belitung, tindakan pengoplosan beras yang terjadi di Cianjur, dan tindakan pengoplosan beras dengan sabun di Gresik.

Toko Beras Jaya Abadi yang terletak di Jalan Trem Pangkalpinang, Bangka Belitung, adalah salah satu contoh pelaku usaha yang tidak beritikad baik. Masyarakat yang merupakan konsumen atau yang

2) Indonesia, Undang-Undang Nomor 8 Tahun 1999 tentang Perlindungan Konsumen (Lembaran Negara Republik Indonesia tahun 1999 No. 42 Tambahan lembaran Negara Republik Indonesia No. 3821), Pasal 1 ayat (1).

3) Ibid., Pasal 4.

4) Ibid., Pasal 5.

5) Ibid., Pasal 6.

6) Ibid., Pasal 7

7) Ibid., Pasal 8-17 
membeli beras dari Toko ini mengadukan bahwa beberapa merek beras yang dijual oleh Toko Jaya Abadi ini menjual beras oplosan yang dicampur dengan beras bulog. Dari putusan Pengadilan Negeri Nomor: 56/Pid.Sus/2017/PN.Pgp, diketahui bahwa modus dari pemilik Toko Jaya Abadi adalah memasukkan beras bulog ke karung beras bermerek kemudian dijahit rapi sebelum dijual. Selisih harga jual antara beras bulog dengan beras merk ini mencapai Rp 1.500.- per kilogramnya. Hal yang dilakukan ini memberi keuntungan yang sangat banyak bagi pemiliknya. Dari kegiatan tersebut, dapat dibuktikan bahwa pemilik Toko Jaya Abadi tidak memiliki itikad baik dalam melakukan kegiatan usahanya. Polisi kemudiaan mengamankan pemilik Toko Jaya Abadi Cristian Chandra dan pekerjanya Dv. Selain mengamankan kedua tersangka, pihaknya juga telah mengamankan barang bukti berupa beras sebanyak 2,5 ton dalam 49 karung dengan ukuran 50 kilogram. ${ }^{8)}$

Pengoplosan beras juga terjadi di Cianjur, tepatnya di Kampung Cimaja, Desa Cikahurupan, Kecamatan Gekbrong. Sebanyak 10 ton beras raskin yang sudah dioplos ditemukan di sebuah gudang yang berkedok sebagai tempat penggilingan padi. Dari hasil pemeriksaan oleh Polsek Warungkondang, beras raskin yang berada di gudang berasal dari jatah masyarakat pra sejahtera di Desa Titisan, Kecamatan Sukalarang, Kabupaten Sukabumi. Dalam menjalankan tindakan pengoplosan tersebut, para pengoplos beras terlebih dahulu membersihkan beras raskin agar terlihat bagus. Selanjutnya beras dimasukan dalam kemasan beras dengan Merek beras Slyp Super LG Cianjur ukuran 25 kilogram dan 50 kilogram. Setelah dikemas sedemikian rupa, beras hasil pengoplosan tersebut kemudian dijual ke masyarakat sekitar. ${ }^{9)}$

Tindakan pengoplosan juga terjadi di Gresik dengan cara yang serupa dengan yang terjadi di Pangkalpinang dan Cianjur. Tindakan

${ }^{8)}$ Putusan Nomor 56/Pid.Sus/2017/PN.Pgp.

9) Anonim, "Polisi Gerebek Gudang Pengoplos Beras di Cianjur", https://www.liputan6.com/news/read/3181331/polisi-gerebek-gudang-pengoplos-beras-di-cianjur, 30 November 2017. 
pengoplosan ini tepatnya terjadi di Desa Terongbangi, Desa Kandangan, Kecamatan Cerme, Gresik, Jawa Timur. Tindakan pengoplosan ini diketahui sudah dilakukan sejak tahun 2013 dengan area peredaran berada di wilayah Gresik. Tindakan ini dilakukan dengan cara pelaku mencampurkan beras kusam dengan air bersih sekitar 10 liter yang sebelumnya telah lebih dulu dicampur dengan dua tutup botol sabun pencuci piring. Setelah itu semua bahan dicampur dan diaduk secara merata. Dengan begitu, beras yang awalnya berwarna kecoklat-coklatan lantas berubah menjadi putih bersih dan layak dijual di pasaran dan menambah nilai ekonomis. Beras tersebut dikemas dengan Merek Cendrawasih Spesial dan merek Ikan Paus yang dipasarkan di daerah Gresik. Akibat dari tindakan ini, masyarakat yang membeli beras tersebut kemudian melaporkan ke Polisi setempat karena beras oplosan yang dijual tersebut mengeluarkan busa saat dicuci. Polisi dalam tindakan membongkar praktek pengoplosan beras ini kemudian menemukan barang bukti 1,5 ton beras yang sudah di beri pemutih. ${ }^{10)}$

Dari adanya kegiatan pengoplosan yang terjadi di Toko Jaya Abadi Pangkalpinang, Cianjur dan Gresik ini dapat dilihat bahwa kegiatan pengoplosan beras ini menimbulkan keresahan di dalam masyarakat setempat. Keresahan masyarakat menimbulkan permasalahan dimana hak masyarakat untuk memperoleh keamanaan dalam mengkonsumsi barang yang di jual oleh pelaku usaha dikesampingkan karena tindakan pelaku usaha. Selain itu, masyarakat merasa dirugikan karena tindakan pengoplosan ini secara tidak langsung berarti melakukan penipuan dan beras yang dijual oleh pelaku usaha tersebut tidaklah sesuai dengan standar yang dimaksud sebelumnya. Dapat dilihat bahwa kegiatan pengoplosan ini telah melanggar ketentuan yang ada di dalam UUPK,

${ }^{10)}$ Anonim, "Polisi Bongkar Praktik Pengoplosan Beras dengan Sabun di Gresik", https://regional.kompas.com/read/2017/05/29/08432741/polisi.bongkar.praktik.pengoplosan.beras. dengan.sabun.di.gresik, 29 Mei 2017. 
dimana pelaku usaha dilarang menjual suatu produk atau barang tidak sesuai dengan standar yang berlaku atau yang diperjanjikan.

\section{B. Perumusan Masalah}

Penulis setelah mengungkapkan hal-hal diatas, berkinginan untuk merumuskan permasalahan sebagai berikut:

1. Apa bentuk perlindungan hukum terhadap hak konsumen atas keamanan dalam mengkonsumsi barang dari tindakan pengoplosan beras?

2. Apa peran pemerintah dalam mengawasi peredaran beras dalam rangka perlindungan hak konsumen terhadap keamanan dalam mengkonsumsi barang dari tindakan pengoplosan beras?

\section{Metode Penelitian}

Metode penelitian hukum yang digunakan penulis adalah metode normatif, artinya penelitian ini meneliti hukum dari perspektif internal dengan objek penelitiannya adalah norma hukum. Metode penelitian hukum normatif berfungssi memberi argumentasi yuridis ketika terjadi kekosongan, kekaburan, dan konflik norma. ${ }^{11)}$ Penelitian ini bersifat preskriptif, menggunakan jenis pendekatan perundang-undangan (Statute Approach) dan pendekatan konseptual. Bahan hukum yang digunakan dalam penulisan terdiri dari bahan hukum primer, bahan hukum sekunder dan bahan non-hukum untuk menunjang penelitian. Bahan hukum primer yang digunakan adalah Standar Nasional Indonesia (SNI) 6128:2015 tentang Beras, Putusan Pengadilan Negeri Pangkalpinang Nomor: 56/Pid.Sus/2017/PN.Pgp., Peraturan Menteri Perdagangan Republik Indonesia Nomor 20/M-DAG/PER/5/2009 tentang Ketentuan dan Tata Cara Pengawasan Barang dan/atau Jasa, Undang-Undang Nomor 18 Tahun 2012 tentang Pangan dan Undang-Undang Nomor 8 Tahun 1999 tentang Perlindungan Konsumen. Bahan hukum sekunder dalam penelitian ini bersumber dari buku, jurnal ilmiah, bahan yang diperoleh dari internet,

11) I Made Pasek Diantha, Metode Penelitian Hukum Normatif Dalam Judifikasi Teori Hukum, (Jakarta: Prenada Media Group, 2016), hal. 12. 
teori atau pendapat para sarjana, makalah, majalah, dan surat kabar. Sumber bahan non-hukum dapat berupa wawancara dengan narasumber (ahli hukum) sebagai upaya mendapatkan pendapat hukum tentang obyek yang diteliti, ataupun laporan-laporan penelitian non-hukum dan jurnal non-hukum sepanjang mempunyai relevansi dengan topik penulisan skripsi. ${ }^{12)}$

\section{PEMBAHASAN}

\section{A. Perlindungan Hukum Terhadap Hak Konsumen Dalam}

\section{Mengkonsumsi Barang dari Tindakan Pengoplosan Beras.}

Kegiatan usaha sejatinya menjadi suatu kegiatan ekonomi yang dilakukan masyarakat luas dengan tujuan untuk memperoleh keuntungan dan mendapatkan penghasilan guna memenuhi kebutuhan hidupnya sehari-hari. Kegiatan usaha ini sering kali disebut sebagai perdagangan. Kegiatan usaha kemudian dilakukan oleh pedagang atau pelaku usaha. Suatu kegiatan ini dikatakan sebagai menjalankan usaha apabila memenuhi kriteria, antara lain status atau kedudukan tertentu, terusmenerus, sah atau legal, dan tujuan mencari laba. ${ }^{13)}$

Kegiatan usaha yang dilakukan pelaku usaha apabila dilihat dari kriteria di atas, maka dapatlah dikatakan bahwa pelaku usaha tersebut telah menjalankan kegiatan usaha dengan status sebagai pedagang beras yang dikenal oleh masyarakat sekitar, kegiatan yang terus-menerus dilakukan oleh pelaku usaha sebagai pekerjaannya, kegiatan usahanya sah atau legal karerna tidak bertentangan dengan hukum dan bertujuan untuk mencari laba atau keuntungan.

Kegiatan usaha sejatinya dilakukan dengan niat atau itikad baik dari pelaku usaha juga dari konsumen sebagai pembeli. Namun tidak semua kegiatan usaha ini kemudian sesuai dengan yang diharapkan. Salah satunya adalah tindakan pengoplosan beras.

${ }^{12)}$ Peter Mahmud Marzuki, Penelitian Hukum Edisi Revisi, (Jakarta: Kencana Prenada Media Group, 2010). hal. 164.

13) Agus Sardjono et al., Pengantar Hukum Dagang, (Depok: PT Rajagrafindo Persada, 2014), hal. 30. 
Tindakan pengoplosan beras merupakan salah satu bentuk tindakan yang dilakukan oleh pelaku usaha tanpa itikad yang baik atau tidak beritikad baik dan pada akhirnya menimbulkan kerugian bagi konsumen yang membeli barang yang dijual atau diperdagangkan oleh pelaku usaha. Tindakan ini semata-mata bertujuan untuk mencari laba atau keuntungan sebanyak-banyaknya.

Pengoplosan beras sebagaimana terkait dengan 3 fakta hukum yang ada, yaitu kasus pengoplosan beras di Pangkalpinang, pengoplosan beras di Cianjur dan pengoplosan beras di Gresik, dapat dilihat bahwa tindakan yang dilakukan oleh pelaku usaha sangatlah merugikan konsumen sebagai pembeli dan yang mengkonsumsi beras tersebut. Pengoplosan yang dilakukan terhadap beras ini apabila diteliti lebih lanjut, dapat dilihat bahwa pelaku usaha telah menjual atau memperdagangkan beras yang tidak sesuai dengan merek atau label yang tercantum di kemasan beras tersebut. Selain itu, dalam fakta hukum pengoplosan beras di Pangkalpinang, Cianjur dan Gresik dapat dilihat bahwa beras yang dioplos merupakan beras BULOG yang seharusnya di jual murah atau di di distribusikan ke daerah-daerah sebagai beras miskin justru di gunakan sebagai beras untuk di oplos sehingga terlihat berkualitas baik, dikemas ulang dalam merek terkenal dan di jual ke pasaran dengan harga yang relatif lebih tinggi untuk memperoleh keuntungan sebanyak-banyaknya.

Tindakan pengoplosan secara jelas melanggar asas itikad baik sebagaimana tertera dalam Pasal 1338 ayat (3) KUHPerdata, dimana menurut pasal ini "suatu perjanjian harus dilaksanakan dengan itikad baik". Perjanjian dalam pasal 1338 ayat (3) KUHPerdata ini dapat dikaitkan dengan kegiatan jual beli antara pelaku usaha dengan konsumen sebagai pembeli. Asas ini juga ditekankan dalam kewajiban pelaku usaha 
dalam Pasal 7 huruf a UUPK ${ }^{14)}$, dimana kewajiban pelaku usaha adalah beritikad baik dalam menjalankan kegiatan usahanya.

Tindakan pengoplosan beras tidak hanya melanggar Pasal 7 huruf a tentang beritikad baik dalam menjalankan kegiatan usahanya, tetapi juga melanggar pasal lain, yaitu Pasal 4 huruf a, b, c UUPK tentang hak konsumen, dan Pasal 7 huruf $b$ dan d UUPK tentang kewajiban pelaku usaha. Pasal 4 UUPK berisikan hak konsumen. Hak konsumen diatur dalam Pasal 4 UUPK, dimana menurut Pasal 4 UUPK, hak konsumen adalah: hak atas kenyamanan, keamanan, dan keselamatan dalam mengkonsumsi barang dan/atau jasa; hak untuk memilih barang dan/atau jasa serta mendapatkan barang dan/atau jasa tersebut sesuai dengan nilai tukar dan kondisi serta jaminan yang dijanjikan; hak atas informasi yang benar, jelas, dan jujur mengenai kondisi dan jaminan barang dan/atau jasa; hak untuk didengar pendapat dan keluhannya atas barang dan/atau yang digunakan; hak untuk mendapatkan advokasi, perlindungan, dan upaya penyelesaian sengketa perlindungan konsumen secara patut; hak untuk mendapat pembinaan dan pendidikan konsumen; hak untuk diperlakukan atau dilayani secara benar dan jujur serta tidak diskriminatif; hak untuk mendapatkan kompensasi, ganti rugi dan/atau penggantian, apabila barang dan/atau jasa yang diterima tidak sesuai dengan perjanjian atau tidak sebagaimana mestinya; hak-hak yang diatur dalam ketentuan peraturan perundang-undangan lainnya. ${ }^{15)}$ Pasal 7 UUPK berisi kewajiban konsemen dalam melakukan kegiatan usaha. Kewajiban pelaku dalam Pasal 7 UUPK adalah: beritikad baik dalam melakukan kegiatan usahanya; memberikan informasi yang benar, jelas dan jujur mengenai kondisi dan jaminan barang dan/atau jasa serta memberi penjelasan penggunaan, perbaikan dan pemeliharaan; memperlakukan atau melayani konsumen secara benar dan jujur serta tidak diskriminatif; menjamin

${ }^{14)}$ Indonesia, Undang-Undang Nomor 8 Tahun 1999 tentang Perlindungan Konsumen (Lembaran Negara Republik Indonesia Tahun 1999 Nomor 22, Tambahan Lembaran Negara Republik Indonesia Nomor 3821), Pasal 7 huruf a.

15) Ibid., Pasal 4. 
mutu barang dan/atau jasa yang diproduksi dan/atau diperdagangkan berdasarkan ketentuan standar mutu barang dan/atau jasa yang berlaku; memberi kesempatan kepada konsumen untuk menguji, dan/atau mencoba barang dan/atau jasa tertentu serta memberi jaminan dan/atau garansi atas barang yang dibuat dan/atau yang diperdagangkan; memberi kompensasi, ganti rugi dan/atau penggantian atas kerugian akibat penggunaan, pemakaian dan pemanfaatan barang dan/atau jasa yang diperdagangkan; memberi kompensasi, ganti rugi dan/atau penggantian apabila barang dan/atau jasa yang diterima atau dimanfaatkan tidak sesuai dengan perjanjian. ${ }^{16)}$ Kewajiban ini bila dikaitkan dengan fakta hukum tindakan pengoplosan beras, akan terlihat bahwa pelaku usaha telah melanggar kewajiban pelaku usaha dalam UUPK dalam hal beritikad baik dalam melakukan kegiatan usahanya, memberikan informasi yang benar, jelas, dan jujur mengenai kondisi barang, menjamin mutu barang yang diproduksi dan/atau diperdagangkan berdasarkan ketentuan standar mutu barang dan/atau jasa yang berlaku, serta memberi kompensasi, ganti rugi dan/atau penggantian apabila barang yang diterima atau dimanfaatkan tidak sesuai dengan perjanjian. ${ }^{17)}$

Tindakan pengoplosan sebagaimana telah diatur dalam UUPK dapat dikategorikan sebagai perbuatan yang dilarang bagi pelaku usaha. UUPK sendiri telah mengatur perbuatan yang dilarang ini pada Pasal 8 sampai dengan Pasal 17, dimana tindakan pengoplosan telah melanggar beberapa ketentuan, antara lain:

a. Pelaku usaha dilarang memproduksi atau memperdagangkan barang yang tidak memenuhi atau tidak sesuai dengan standar yang di persyaratkan. ${ }^{18)}$

b. Pelaku usaha dilarang memperdagangkan barang yang cacat atau tercemar, dengan atau tanpa memberikan informasi secara lenkap dan benar. ${ }^{19)}$

\footnotetext{
16) Ibid., Pasal 7.

17) Ibid., Pasal 7.

${ }^{18)}$ Ibid., Pasal 8 ayat (1) huruf a.
} 
c. Pelaku usaha dilarang memperdagangkan sediaan pangan yang rusak, cacat atau bekas dan tercemar, dengan atau tanpa memberikan informasi secara lengkap dan benar. ${ }^{20)}$

d. Pelaku usaha dilarang menawarkan, memproduksi, mengiklankan suatu barang secara tidak benar dan/atau seolah-olah barang tersebut telah memenuhi standar mutu tertentu, barang tersebut dalam keadaan baik dan/atau baru ataupun barang tersebut tidak mengandung cacat tersembunyi. ${ }^{21)}$

Pengoplosan beras bila di kaitkan dengan ketentuan di atas, maka dapat di lihat bahwa kegiatan yang dilakukan pelaku usaha tersebut melanggar ketentuan yang ada di UUPK. Di mulai dengan tindakan pelaku usaha yang menggunakan beras BULOG sebagai beras yang di jual kembali. Penggunaan beras BULOG ini tentu merupakan hal yang dilarang pelaku usaha dimana pelaku usaha dilarang memproduksi dan/atau memperdagangkan barang yang tidak sesuai janji yang dinyatakan dalam label. Beras BULOG di kemas ulang dalam berbagai merek yang kemudian di jual ke masyarakat tentu merugikan banyak pihak, terutama konsumen yang mengkonsumsi atau membeli beras tersebut, karena beras yang di beli tersebut sangat berbeda dengan beras yang di perjanjikan, atau yang tertera pada label, atau yang sebagaimana seharusnya.

Pengemasan kembali tidak hanya dilarang oleh UUPK, tetapi juga dalam UU Pangan. Dalam Pasal 84 UU Pangan dikatakan bahwa setiap orang dilarang membuka kemasan akhir pangan untuk dikemas kembali dan diperdagangkan. ${ }^{22)}$ Selain itu, Pasal 89 UU Pangan juga mengatakan bahwa setiap orang dilarang memperdagangkan pangan yang tidak sesuai

${ }^{19)}$ Ibid., Pasal 8 ayat (2).

${ }^{20)}$ Ibid., Pasal 8 ayat (3).

21) Ibid., Pasal 9.

${ }^{22)}$ Indonesia, Undang-Undang Nomor 18 Tahun 2012 tentang Pangan (Lembaran Negara Republik Indonesia tahun 2012 No. 227 Tambahan lembaran Negara Republik Indonesia No. 5360), Pasal 83. 
dengan keamanan dan mutu pangan yang tercantum dalam label kemasan pangan. $^{23)}$

Kegiatan lain yang juga merupakan perbuatan yang dilarang bagi pelaku usaha adalah menggunakan bahan lain atau bahan asing nonpangan berupa sabun sebagai bahan untuk mencuci atau membersihkan beras agar terlihat putih dan nampak seperti beras berkualitas baik. Hal ini jika dikaitkan dengan UUPK merujuk pada ketentuan dimana pelaku usaha dalam hal menjual atau memperdagangkan produk pangan dilarang untuk memperdagangkan sediaan pangan yang rusak, cacat, atau bekas, dan tercemar, dengan atau tanpa memberikan informasi secara lengkap dan benar. ${ }^{24)}$ Tidak hanya UUPK, UU Pangan juga mengatur tentang keamanan dalam pangan, dimana dalam Pasal 90 UU Pangan dikatakan bahwa setiap orang dilarang mengedarkan pangan tercemar yang mengandung bahan beracun, berbahaya, atau yang dapat membahayakan kesehatan atau jiwa manusia, serta bahan yang dilarang digunakan untuk kegiatan atau proses produksi pangan. ${ }^{25)}$ Jika dikaitkan dengan Pasal 90 UU Pangan ini, maka semakin terbukti bahwa penggunaan sabun sebagai bahan untuk membersihkan beras agar terlihat mempunyai kualitas yang baik itu dilarang karena melanggar hak konsumen dalam mendapatkan keamanan dalam mengkonsumsi barang yang dibeli dari pelaku usaha tersebut, karena pada dasarnya sabun merupakan bahan kimia yang tidak untuk dikonsumsi dan dapat membahayakan kesehatan manusia apabila bahan tersebut dikonsumsi oleh masyarakan sebagai konsumen, seperti keracunan, gangguan pencernaan, dan lain-lain.

Pelanggaran yang terjadi pada tindakan pengoplosan beras sepenuhnya merupakan tanggung jawab dari pelaku usaha sebagai pihak

23) Ibid., Pasal 89.

${ }^{24)}$ Indonesia, Undang-Undang Nomor 8 Tahun 1999 tentang Perlindungan Konsumen (Lembaran Negara Republik Indonesia Tahun 1999 Nomor 22, Tambahan Lembaran Negara Republik Indonesia Nomor 3821), Pasal 8 ayat 3.

${ }^{25)}$ Indonesia, Undang-Undang Nomor 18 Tahun 2012 tentang Pangan (Lembaran Negara Republik Indonesia tahun 2012 No. 227 Tambahan lembaran Negara Republik Indonesia No. 5360), Pasal 90. 
yang memproduksi atau memperdagangkan barang tersebut. Bila dilihat dari fase terjadinya sengketa atau pelanggaran konsumen, tindakan pengoplosan beras dapat kita sebut sebagai pelanggaran pada fase pratransaksi dan fase transaksi. ${ }^{26)}$

Pelanggaran pada fase pratransaksi berarti pelanggaran pada sebelum terjadinya transaksi jual beli antara pelaku usaha dengan konsumen. Pelanggaran pada fase ini terjadi ketika pelaku usaha melakukan tindakan pengoplosan beras, mulai dari memindahkan beras, mencampur beras dengan bahan non-pangan, mengemas ulang beras dengan merek beras yang lain hingga proses beras tersebut diperdagangkan ke masyarakat. Kemudian pelanggaran juga terjadi pada fase transaksi, atau fase pada saat dilakukannya jual beli antara pelaku usaha dengan pembeli atau konsumen. Pelanggaran pada fase ini terjadi karena penjual telah menjual atau memperdagangkan barang yang sudah tidak layak untuk diperdagangkan karena tidak sesuai lagi mutu atau standar beras yang dijual dan beras yang dibeli konsumen tersebut isinya tidak sesuai dengan merek atau label beras yang ada pada kemasan, karena bukan beras premium yang diterima konsumen, melainkan beras BULOG yang sudah dioplos dan dikemas ulang kedalam kemasan merek lain.

Pengplosan beras sangat merugikan konsumen yang membeli dan mengkonsumsi beras tersebut, terutama dalam hal keamanan konsumen dalam mengkonsumsi beras hasil pengoplosan tersebut. Sebagai akibatnya, pelaku usaha haruslah bertanggung jawab dalam hal memberikan ganti rugi karena memberikan barang yang tidak sesuai dengan janji sekaligus berbahaya bagi konsumen. Dalam UUPK, tanggung jawab ini sebagai bentuk perlindungan refresif bagi konsumen, dimana perlindungan hukum refresif ini berfungsi untuk menyelesaikan

26) Janus Sidabolak., Hukum Perlindungan Konsumen di Indonesia, Cetakan ke-3 (Bandung: PT Citra Aditya Bakri, 2014), hal. 59. 
permasalahan apabila terjadi sengketa. ${ }^{27)}$ Tanggung jawab pelaku usaha dalam UUPK antara lain memberikan ganti rugi atas kerugian konsumen sebagai akibat mengkonsumsi barang yang dihasilkan atau diperdagangkan oleh pelaku usaha. Ganti rugi ini juga merupakan hak konsumen sebagaimana diatur dalam Pasal 4 UUPK, dan menjadi kewajiban bagi pelaku usaha untuk mengembalikan uang konsumen sebagai bentuk ganti rugi, ataupun mengganti barang yang telah dibeli oleh konsumen dengan barang yang selayaknya atau seharusnya diperoleh konsumen.

Tindakan pengoplosan beras secara umum dapat di kategorikan sebagai tindak pidana khusus konsumen, karena tindakan yang dilakukan pelaku usaha itu merupakan penipuan bagi konsumen dan merugikan konsumen. Sebagai akibatnya, UUPK memberikan sanksi berupa sanksi pidana. Sesuai dengan pelanggaran yang telah dilakukan oleh pelaku usaha, yaitu pada Pasal 8 UUPK terkait pelarangan pelaku usaha untuk memproduksi dan/atau memperdagangkan barang yang tidak memenuhi atau tidak sesuai dengan standar yang dipersyaratkan dari ketentuan perundang-undangan, ${ }^{28)}$ maka menurut Pasal 62 UUPK, pelaku usaha yang melanggar Pasal 8 UUPK dapat dipidana dengan pidana penjara paling lama 5 (lima) tahun atau pidana denda paling banyak Rp 2.000.000.000,00 (dua milyar rupiah), ${ }^{29)}$ serta dapat juga dijatuhkan pidana tambahan sebagaimana pada Pasal 63 diatur pidana tambahan yang dapat berupa perampasan barang tertentu, pengumuman keputusan hakim, pembayaran ganti rugi, perintah penghentian kegiatan tertentu

${ }^{27)}$ H. Salim HS dan Erlies Septiana Nurbani, Penerapan Teori Hukum Pada Penelitian Tesis dan Disertasi, (Jakarta: PT Rajagrafindo Persada, 2013), hal. 264.

${ }^{28)}$ Indonesia, Undang-Undang Nomor 8 Tahun 1999 tentang Perlindungan Konsumen (Lembaran Negara Republik Indonesia tahun 1999 No. 42 Tambahan lembaran Negara Republik Indonesia No. 3821), Pasal 8.

29) Ibid., Pasal 62. 
yang menyebabkan timbulnya kerugian konsumen, penarikan barang dari peredaran oleh pelaku usaha, atau pencabutan izin usaha. ${ }^{30)}$

Tanggung jawab pelaku usaha dan pemberian sanksi tidak hanya diberikan oleh UUPK, tetapi juga oleh UU Pangan. Tindakan pengoplosan beras secara jelas telah melanggar UU Pangan terutama dalam hal keamanan pangan itu sendiri. Terhadap pelanggaran ini, UU Pangan kemudian memberikan sanksi terhadap terjadinya pelanggaran di atas. Sanksi yang di berikan dalan UU Pangan berupa sanksi admisintratif. Sanksi administratif yang dimaksud ini dapat berupa denda, penghentian sementara dari kegiatan produksi dan/atau peredaran, penarikan pangan dari peredaran, ganti rugi, dan/atau pencabutan izin. Tidak hanya sanksi administratif, UU Pangan juga mengatur sanksi pidana, dimana sesuai dengan tindakan pengoplosan beras yang dilakukan, sanksi yang dapat diterima oleh pelaku usaha antara lain:

1. Pasal 136 UU Pangan, yaitu pidana penjara paling lama 5 (lima) tahun atau denda paling banyak Rp10.000.000.000,00 (sepuluh milyar rupiah) apabila melakukan produksi pangan untuk diedarkan dengan sengaja menggunakan bahan yang dilarang digunakan sebagai tambahan pangan sebagaimana dimaksud dalam pasal 75 ayat (1) UU Pangan. ${ }^{31)}$

2. Pasal 139 UU Pangan, yaitu pidana penjara paling lama 5 (lima) tahun atau denda paling banyak Rp10.000.000.000,00 (sepuluh milyar rupiah) apabila dengan sengaja membuka kemasan akhir pangan untuk dikemas kembali dan diperdagangkan sebagaimana dimaksud dalam Pasal 84 UU Pangan. ${ }^{32)}$

3. Pasal 141 UU Pangan, yaitu pidana penjara paling lama 2 (dua) tahun atau denda paling banyak Rp4.000.000.000,00 (empat milyar rupiah)

${ }^{30)}$ Ibid., Pasal 63.

${ }^{31)}$ Indonesia, Undang-Undang Nomor 18 Tahun 2012 tentang Pangan (Lembaran Negara Republik Indonesia tahun 2012 No. 227 Tambahan lembaran Negara Republik Indonesia No. 5360), Pasal 136.

${ }^{32)}$ Ibid., Pasal 139. 
apabila dengan sengaja memperdagangkan pangan yang tidak sesuai dengan keamanan pangan dan mutu pangan yang tercantum dalam label kemasan pangan sebagaimana dimaksud dalam Pasal 89 UU Pangan. ${ }^{33)}$

Dari analisis di atas, dapat disimpulkan bahwa perlindungan hukum yang dapat diterima konsumen dalam hal tindakan pengoplosan beras tersebut sudah diatur oleh UUPK juga UU Pangan. Bentuk perlindungan hukum ini dapat dilihat dari adanya hak yang diberikan oleh UUPK kepada konsumen sebagai jaminan akan perlindungan bagi konsumen dalam melakukan kegiatan jual beli dengan pelaku usaha, terutama terhadap pelaku usaha yang tidak beritikad baik seperti pelaku usaha yang melakukan pengoplosan beras ataupun kegiatan lain yang merugikan konsumen. Selain itu, UU Pangan juga memberikan pengatutan tentang bagaimana pangan yang seharusnya layak untuk diterima oleh masyarakat kepada konsumen agar sekiranya konsumen di Indonesia memperoleh kebutuhan pangan yang aman, tidak berbahaya, layak dikonsumsi serta menjamin gizi baik yang terkandung pada setiap produk pangan yang ada di pasaran. Perlindungan hukum juga diberikan oleh UUPK dan UU Pangan dengan diterapkannya sanksi atas adanya pelanggaran yang dilakukan oleh para pelaku usaha yang merugikan konsumen. Sanksi ini dapat berupa ganti rugi, penarikan produk, pidana penjara hingga pencabutan izin usaha dari pemerintah.

\section{B. Peran Pemerintah Dalam Rangka Perlindungan Hak Konsumen} Terhadap Keamanan Dalam Mengkonsumsi Barang Dari Tindakan Pengoplosan Beras.

Peran atau peranan merupakan bagian dari suatu tugas yang harus dilaksanakan dan memiliki tujuan tertentu. ${ }^{34)}$ Dalam rangka melindungi hak konsumen, pemerintah haruslah ikut serta dalam mengawasi seluruh

33) Ibid., Pasal 141.

${ }^{34)}$ H. Salim HS dan Erlies Septiana Nurbani, Penerapan Teori Hukum Pada Penelitian Tesis dan Disertasi (Buku Kedua), (Jakarta: PT Rajagrafindo Persada, 2014), hal. 141. 
kegiatan perekonomian yang terjadi di masyarakat di seluruh daerah. Upaya untuk melindungi konsumen ini kemudian dilakukan dengan melakukan pengawasan terhadap barang dan/atau jasa yang beredar di masyarakat. Bila dikaitkan dengan fakta hukum tentang tindakan pengoplosan beras, pemerintah haruslah turut serta melakukan pengawasan terhadap peredaran beras yang ada di masyarakat agar terjamin kesehatan, keamanan, dan kenyamanan masyarakat yang sekaligus menjadi konsumen yang membeli, menggunakan atau mengkonsumsi barang dan/atau jasa yang beredar di masyarakat.

Peran pemerintah dalam melakukan pengawasan terhadap barang beredar ini kemudian diatur oleh Kementerian Perdagangan Republik Indonesia. Menteri Perdagangan kemudian mengeluarkan Peraturan Menteri Perdagangan Republik Indonesia Nomor 20/M-DAG/PER/5/2009 tentang Ketentuan dan Tata Cara Pengawasan Barang dan/atau Jasa (PERMENDAG No. 20 Tahun 2009).

Pasal 1 ayat 21 PERMENDAG No. 20 Tahun 2009 memberikan pengertian tentang pengawasan, dimana pengawasan adalah serangkaian kegiatan yang dilakukan oleh petugas pengawas untuk memasikan kesesuaian barang dan/atau jasa dalam memenuhi standat mutu produksi barang dan/atau jasa, pencantuman label, klausula baku, caara menjual, pengiklanan, pelayanan purna jual, dan kebenaran peruntukan distribusinya. ${ }^{35)}$ Pengawasan ini dibagi menjadi dua, yaitu pengawasan berkala dan pengawasan khusus. Pengawasan berkala adalah pengawasan barang dan/atau jasa yang dilakukan dalam waktu tertentu berdasarkan prioritas barang dan/atau jasa yang akan diawasi sesuai program. ${ }^{36}$ Sedangkan pengawasan khusus adalah pengawasan yang dilakukan sewaktu-waktu berdasarkan adanya temuan indikasi pelanggaran, laporan pengaduan konsumen atau masyarakat, Lembaga Perlindungan Konsumen

${ }^{35)}$ Indonesia, Peraturan Menteri Perdagangan Republik Indonesia Nomor 20/MDAG/PER/5/2009 tentang Ketentuan dan Tata Cara Pengawasan Barang dan/atau Jasa. (Berita Negara Republik Indonesia tahun 2009 No. 204), Pasal 1 Ayat 21.

36) Ibid., Pasal 1 ayat 22. 
Swadaya Masyarakat (LPKSM) atau tindak lanjut dari hasil pengawasan berkala, atau adanya informasi, baik yang berasal dari media cetak, media elektronik, maupun media lainnya. ${ }^{37)}$ Kegiatan pengawasan dapat dilakukan oleh masyarakat, LPKSM dan pemerintah. Pengawasan yang dilakukan pemerintah ini dilakukan oleh Petugas Pengawas Barang dan Jasa (PPBJ), dimana PPBJ adalah Pegawai Negeri Sipil yang berada di lingkungan unit atau organisasi yang bertanggung jawab dalam penyelenggaraan pengawasan barang dan/atau jasa atau penyelenggaraan perlindungan konsumen di bidang perdagangan yang ditujukan untuk dan diangkat oleh pejabat yang berwenang. ${ }^{38)}$

Ruang lingkup pengawasan pada dasarnya dilakukan pada barang dan/atau jasa yang beredar di pasar, barang yang dilarang beredar di pasar, barang yang diatur tata niaganya, perdagangan barang-barang dalam pengawasan, dan distribusi. ${ }^{39)}$ Pengawasan tidak hanya dilakukan oleh pemerintah, tapi masyarakat dan LPKSM juga dapat membantu pengawasan barang yang beredar di pasar.

Kegiatan pengawasan pada dasarnya bertujuan untuk menjaga keamanan mutu atau kualitas barang agar sesuai dengan SNI atau standar yang diberlakukan pada barang tersebut, serta menjaga distribusinya di tiap daerah di Indonesia. Kegiatan ini dapat dilakukan dengan melakukan pengecekann dan/atau pengujian di laboratorium terhadap barang yang beredar di pasaran. Bila dikaitkan dengan fakta hukum, apabila terjadi pengoplosan beras, Kepala Dinas setempat di daerah masing-masing akan menyampaikan laporan hasil pengawasan dan pelaksanaan penyidikan kepada Bupati/Walikota setempat dan Kepala Dinas di daerah Provinsi. ${ }^{40)}$

Pengawasan terhadap adanya tindakan pengoplosan beras yang dilakukan oleh pemerintah ditugaskan kepada PPBJ dengan melakukan pengecekan dan/atau pengujian di laboratorium. Kegiatan pengujian

\footnotetext{
37) Ibid., Pasal 1 ayat 23.

38) Ibid., Pasal 1 ayat 24.

39) Ibid., Pasal 2 ayat 1.

${ }^{40)}$ Ibid., Pasal 44 ayat 1.
} 
dan/atau pengecekan ini dilakukan dengan mengambil sampel melalui pembelian secara acak, melakukan pengamatan kasat mata terhadap keterangan yang tercantum dalam label, dan memastikan kebenaran antara keterangan yang tercantum dalam label dengan kondisi barang yang sebenarnya. ${ }^{41)}$ Namun bila laporan tentang adanya pengoplosan beras sudah terlebuh dahulu diterima, maka PPBJ mengambil sampel untuk kemudian diuji ke laboratorium uji yang terakreditasi atau yang ditunjuk oleh Menteri teknis yang berwenang. ${ }^{42)}$

Hasil dari pengecekan dan pengujian di laboratorum uji akan menunjukan apakah sampel yang diuji tersebut benar melanggar ketentuan baik di PERMENDAG No. 20 Tahun 2009 maupun UU Pangan. Dalam kaitannya dengan tindakan pengoplosan beras di Gresik, sangat jelas bahwa tindakan pelaku usaha mencampurkan sabun cuci piring untuk membersihkan beras dan membuat beras telihat lebih bersih dan berkualitas itu telah membahayakan keselamatan, keamanan dan kesehatan konsumen, serta merugikan konsumen karena beras yang dijual oleh pelaku usaha tidak sesuai dengan SNI sebagaimana yang telah ditetapkan mengenai beras. Dengan terbuktinya pelanggaran yang dilakukan pelaku usaha melalui hasil uji laboratorium, Menteri dapat memerintahkan kepada pelaku usaha untuk menarik barang yang diproduksi atau yang diperdagangkan tersebut untuk ditarik dari peredaran karena membahayakan keselamatan, keamanan dan kesehatan konsumen dan merugikan konsumen dalam jumlah yang luas. ${ }^{43)}$

Tindakan pengoplosan beras merupakan tindakan yang harus di pertanggungjawabkan oleh pelaku usaha sebagai pelaku atau pihak yang merugikan masyarakat sebagai konsumen. Sebagai salah satu bentuk perlindungan hukum yang diberikan oleh pemerintah kepada konsumen, para pelaku usaha yang melakukan pengoplosan ini dijatuhkan sanksi dari pemerintah. Sesuai dengan PERMENDAG No 20 Tahun 2009, pemerintah

${ }^{41)}$ Ibid., Pasal 25 ayat 1.

42) Ibid., Pasal 25 ayat 2.

${ }^{43)} \mathrm{Ibid}$., Pasal 35 ayat 1. 
dapat menetapkan sanksi administratif bagi pelaku usaha berupa pencabutan Surat Izin Usaha Perdagangan (SIUP) atau pencabutan perizinan teknis lainnya oleh pejabat berwenang. ${ }^{44)}$ Pencabutan SIUP ini dilakukan setelah diberikan peringatan tertulis sebanyan 3 (tiga) kal berturut-turut dengan tenggang waktu masing-masing 7 (tujuh) hari. ${ }^{45)}$

Dari analisis di atas, dapat dilihat bahwa pemerintah haruslah turut andil dalam melakukan pengawasan terhadap barang-barang atau produkproduk yang beredar di masyarakat seperti beras. Pemerintah dalam rangka melindungi hak konsumen terhadap keamanan dalam mengkonsumsi hasil tindakan pengoplosan ini dapat melakukan pengawasan baik secara berkala maupun secara khusus seperti yang sudah diatur di dalam PERMENDAG No. 20 Tahun 2009. Dalam pengawasan ini, melalui PPBJ dapat diambil sampel untuk melakukan pengujian terhadap beras oplosan tersebut dan kemudian memberikan hasil uji itu kepada Menteri agar sekiranya pelaku usaha yang melakukan tindakan pengoplosan tersebut dapat dikenakan sanksi berupa penarikan barang atau beras oplosan tersebut dari peredaran hingga pencabutan SIUP apabila pelaku usaha tetap melakukan tindakan pengoplosan beras. Tindakan inilah yang kemudian menjadi bentuk peran pemerintah dalam menjamin hak konsumen terhadap keamanan dalam mengkonsumsi barang hasil pengoplosan beras tersebut.

\section{PENUTUP}

\section{A. KESIMPULAN}

Perlindungan konsumen merupakan segala bentuk upaya yang menjamin adanya kepastian hukum untuk memberi perlindungan kepada konsumen. ${ }^{46)}$ Upaya menjamin kepastian hukum ini dilakukan dengan

\footnotetext{
44) Ibid., Pasal 45.

45) Ibid., Pasal 46 ayat 1.

${ }^{46)}$ Indonesia, Undang-Undang Nomor 8 Tahun 1999 tentang Perlindungan Konsumen (Lembaran Negara Republik Indonesia tahun 1999 No. 42 Tambahan lembaran Negara Republik Indonesia No. 3821), Pasal 1 ayat 1.
} 
adanya perlindungan hukum yang dapat diterima konsumen dalam hal tindakan pengoplosan beras tersebut sudah diatur oleh UUPK juga UU Pangan. Bentuk perlindungan hukum ini dapat dilihat dari adanya hak yang diberikan oleh UUPK kepada konsumen sebagai jaminan akan perlindungan bagi konsumen dalam melakukan kegiatan jual beli dengan pelaku usaha, terutama terhadap pelaku usaha yang tidak beritikad baik seperti pelaku usaha yang melakukan pengoplosan beras ataupun kegiatan lain yang merugikan konsumen. Selain itu, UU Pangan juga memberikan pengatutan tentang bagaimana pangan yang seharusnya layak untuk diterima oleh masyarakat kepada konsumen agar sekiranya konsumen di Indonesia memperoleh kebutuhan pangan yang aman, tidak berbahaya, layak dikonsumsi serta menjamin gizi baik yang terkandung pada setiap produk pangan yang ada di pasaran. Perlindungan hukum juga diberikan oleh UUPK dan UU Pangan dengan diterapkannya sanksi atas adanya pelanggaran yang dilakukan oleh para pelaku usaha yang merugikan konsumen. Sanksi ini dapat berupa ganti rugi, penarikan produk, pidana penjara hingga pencabutan izin usaha dari pemerintah.

Sebagai bentuk peran pemerintah dalam menjamin keamanan produk yang beredar di pasaran, pemerintah turut andil dalam melakukan pengawasan terhadap barang-barang atau produk-produk yang beredar di masyarakat seperti beras. Ikut sertanya pemerintah ini kemudian menjadi suatu peran bagi pemerintah dalam rangka melindungi hak konsumen terhadap keamanan dalam mengkonsumsi hasil tindakan pengoplosan. Menteri kemudian membentuk PERMENDAG No. 20 Tahun 2009 guna mengatur pengawasan terhadap barang dan/atau jasa yang beredar di masyarakat. Dalam PERMENDAG No. 20 Tahun 2009 ini kemudian dikenal pengawasan berkala berkala dan pengawasan khusus. Dalam pengawasan ini, melalui PPBJ dapat diambil sampel untuk melakukan pengujian terhadap beras oplosan tersebut dan kemudian memberikan hasil uji itu kepada Menteri agar sekiranya pelaku usaha yang melakukan tindakan pengoplosan tersebut dapat dikenakan sanksi berupa penarikan 
barang atau beras oplosan tersebut dari peredaran hingga pencabutan SIUP apabila pelaku usaha tetap melakukan tindakan pengoplosan beras. Tindakan inilah yang kemudian menjadi bentuk peran pemerintah dalam menjamin hak konsumen terhadap keamanan dalam mengkonsumsi barang hasil pengoplosan beras tersebut.

\section{B. SARAN}

1. Konsumen sebaiknya lebih cerdas dan teliti dalam membeli atau mengkonsumsi barang yang dijual di pasaran, terutama beras dan barang pangan lain karena pangan sangat mempengaruhi kesehatan dan keselamatan setiap orang. Konsumen juga harus lebih berani untuk menuntut haknya jika konsumen mengalami kerugian akibat menerima barang yang tidak sesuai dengan yang diperjanjikan.

2. Pelaku usaha haruslah beritikad baik dalam melaksanakan kegiatan usaha atau perdagangannya karena sikap jujur dan bertanggung jawab dalam berusaha sangatlah penting demi keberlangsungan usaha serta harkat martabat pelaku usaha. Pelaku usaha juga harus sadar akan pentingnya kualitas barang, terutama pangan, yang sangat mempengaruhi kesehatan dan keselamatan konsumen yang mengkonsumsi beras hasil pengoplosan tersebut.

3. Pemerintah sebagai instansi yang mengawasi perdagangan harus lebih tegas dalam menerapkan aturan-aturan yang sudah dibuat agar kegiatan usaha yang dijalankan pelaku usaha tidaklah merugikan konsumen dan masyarakat sebagai konsumen merasa terjamin dengan adanya aturan yang melindungi konsumen. Pemerintah juga harus lebih tegas kepada pelaku usaha dalam memberikan sanksi seperti penarikan produk dari pasaran, pemusnahan barang, dan pencabutan izin usaha atau SIUP agar sekiranya menjadi suatu pembelajaran atau pengalaman bagi pelaku usaha itu sendiri dan pelaku usaha yang lain agar menjalankan kegiatan usahanya dengan jujur dan bertanggung jawab. 


\section{DAFTAR PUSTAKA}

\section{A. Buku}

Diantha, I Made Pasek. Metodelogi Penelitian Hukum Normatif Dalam Justifikasi Teori Hukum. (Jakarta: Kencana Prenada Media Group, 2016).

HS, Dr. H. Salim dan Erlies Septiana Nurbani. Penerapan Teori Hukum Pada Penelitian Tesis dan Disertasi. Cetaka Ke-1 (Jakarta: PT RajaGrafindo Persada, 2013)

. Penerapan Teori Hukum Pada Penelitian Tesis dan Disertasi. Cetaka Ke-1 (Jakarta: PT RajaGrafindo Persada, 2014)

Kristiyanti, Celina Tri Siwi. Hukum Perlindungan Konsumen. Edisi Ke-1. Cetakan Ke-3. (Jakarta: Sinar Grafika, 2011)

Marzuki, Peter Mahmud. Penelitian Hukum. Cetakan Ke-2. (Jakarta: Kencana, 2006).

. Penelitian Hukum. Edisi Revisi. Cetakan Ke-8. (Jakarta: Kencana, 2013).

Miru, Ahmadi. Prinsip-prinsip Perlindungan Hukum bagi Konsumen di Indonesia. Cetakan Ke-2 (Jakarta: Rajawali Pers, 2013).

Miru, Ahmadi dan Sutarman Yodo. Hukum Perlindungan Konsumen. Cetakan Ke-9. (Jakarta: PT Raja Grafindo Persada, 2015).

Nasution, Az. Nasution. Hukum Perlindungan Konsumen Suatu Pengantar. Cetakan Ke-3. (Jakarta: Diadit Media).

Nugraha, Susanto Adi. Proses-proses Sengketa Konsumen Ditinjau dari Hukum Acara Serta Kendala Implementasinya. Cetakan Ke-2. (Jakarta: Kencana Prenada Media Group, 2011).

Sardjono, Agus et al. Pengantar Hukum Dagang. Cetakan Ke-3. (Jakarta: PT RajaGrafindo Persada, 2014).

Shidarta. Hukum Perlindungan Konsumen Indonesia. Cetakan Ke-3. (Jakarta: PT Grasindo, 2006). 
Sidabalok, Janus. Hukum Perlindungan Konsumen di Indonesia. Cetakan ke-3. (Bandung: PT Citra Aditya Bakri, 2014).

Soekanto, Soerjono. Pengantar Penelitian Hukum. Cetakan Ke-3. (Jakarta: UI Press, 2005).

Sutedi, Adrian. Tanggung Jawab Produk Dalam Hukum Perlindungan Konsumen. (Jakarta: Ghalia Indonesia, 2008).

\section{B. Peraturan Perundang-undang}

Kitab Undang-Undang Hukum Pidana

Kitab Undang-Undang Hukum Perdata

Indonesia, Undang-Undang Nomor 18 Tahun 2012 tentang Pangan (Lembaran Negara Republik Indonesia Tahun 2012 Nomor 22, Tambahan Lembaran Negara Republik Indonesia Nomor 5360)

, Undang-Undang Nomor 8 Tahun 1999 tentang Perlindungan Konsumen (Lembaran Negara Republik Indonesia Tahun 1999 Nomor 22, Tambahan Lembaran Negara Republik Indonesia Nomor 3821)

, Peraturan Menteri Perdagangan Republik Indonesia Nomor 20/M-DAG/PER/5/2009 Tentang Ketentuan dan Tata Cara Pengawasan Barang dan/atau Jasa (Berita Negara Republik Indonesia Tahun 2009 No. 204)

\section{Artikel, Makalah, dan Internet}

Arfah, Hamzah. "Polisi Bongkar Praktik Pengoplosan Beras dengan Sabun di Gresik", https://regional.kompas.com/read/2017/05/29/08432741/polisi.bongkar.pr aktik.pengoplosan.beras.dengan.sabun.di.gresik, 29 Mei 2017.

Mukiminin, Ferry Amiril. “10 Ton Raskin 'Disulap' Jadi Beras Cianjur yang Mahal, Penggilingan Padi Ini Digerebek", http://www.tribunnews.com/regional/2017/11/30/10-ton-raskin-disulapjadi-beras-cianjur-yang-mahal-penggilingan-padi-ini-digerebek, 30 November 2017.

Sudarno, Achmad. "Polisi Gerebek Gudang Pengoplos Beras di Cianjur", https://www.liputan6.com/news/read/3181331/polisi-gerebek-gudangpengoplos-beras-di-cianjur, 30 November 2017. 
Bahasa, Rubik. "Pengoplosan", https://rubrikbahasa.wordpress.com/2010/08/06/pengoplosan, 6 Agustus 2010.

Departemen Pendidikan dan Kebudayaan, "Pengertian Oplos Mengoplos", http://kbbi.web.id/oplos.mengoplos 